\title{
NOTES ON THE WINTER COLEOPTERA OF WESTERN AND SOUTHERN FLORIDA, WITH DESCRIPTIONS OF NEW SPECIES.
}

\author{
BY W. S. BLATCHLEY, \\ Indianapolis, Ind. \\ (Continued from p. 46).
}

\section{Ptinus tuberculatus, sp. nov.}

Oblong-oval. Head and thorax dark chestnut-brown; elytra dark reddishbrown; antennæ and legs paler brown, densely clothed with prostrate yellowish hairs; under surface reddish-brown, sparsely pubescent with yellowish hairs. Antennæ reaching middle of elytra, second joint one-half the length of fourth; fifth to eleventh subequal, each slightly longer than fourth. Head finely granulate-punctate. Thorax subcylindrical, but slightly wider than head, densely and rather coarsely granulate-punctate and bearing four large conical tubercles arranged in a median cross-row, two above and one each side, each of these bearing a tuft of short, erect yellowish hairs. Elytra oblong, rather strongly convex or ventricose, their strix feebly impressed, each composed of a row of coarse, close-set punctures, which are much wider than the intervals, each puncture bearing a long inclined yellowish hair. First joint of hind tarsi slightly longer than the next two united. Abdomen very finely and sparsely punctate. Length $3.2 \mathrm{~mm}$.

A single specimen, probably a female, was taken while beating alor a blazed roadway in a dense hammock at Cape Sable, Feb. 23. It is different from any species described by Fall, and is unknown to him. The head and thorax are distinctly darker than elytra, and the tuberculate thorax reminds one of the spiked collars often worn by an aristocratic Boston bull terrier.

\section{Heteracthes sablensis, sp. nov.}

Elongate, slender, subcylindrical. Head, thorax, under surface and all the femora and tibiæ dark chestnut-brown; antennæ, elytra and tarsi reddishbrown, the elytra each with a large, elongate-oval, yellow spot at basal third and the apical fifth wholly yellow. Antennæ, as usual with males of the genus, with joints 1-6 much thicker than the others, fourth, two-thirds the length of either third or fifth, the minute second joint obconical. Thorax cylindrical, twice as long as broad, feebly constricted near base, its disk with a low median tubercle, surface minutely granulate-rugose and pubescent with very fine, appressed hairs. Elytra three times as long as thorax, one-third wider at base, their tips subtruncate, the outer apical angle produced as a short spine; surface with scattered small tubercles, thickly and very finely punctate, minutely pubescent. Under surface very finely punctate and pubescent. Length 8.5 $\mathrm{mm}$.

Described from one male swept from low herbs just back of the beach at Cape Sable, Feb. 21. Very distinct from our other species in colour and in the truncate, feebly spined tips of elytra.

Euderces reichei Lec. A half dozen specimens of this small Cerambycid were beaten March 21 from the flowers of a dogwood in Skinner's hammock near Dunedin. The first record for Florida, it being known heretofore only from Indiana, Illinois and Texas. 
Liopus floridanus Ham. Two specimens of this small, dull-coloured Lamiinid were swept from ferns in a dense hammock near Dunedin, March 10-March 24. Described ${ }^{11}$ from Biscayne Bay and not recorded elsewhere.

Lepturges signatus Lec. A single specimen taken at light at Dunedin, June 15. Schwarz records it from Enterprise as "rare."

Spalacopsis filum Chev. This was a common species on dead twigs in the hammocks at Cape Sable and Key West. When stretched out on a twig with their long antennæ at full length in front of them, their gray colour is so similar to that of the bark that they are almost invisible. Although three or four species of this genus have been described or listed from southern Florida, it is very doubtful if more than the one above named really exists in that region.

\section{Exema neglecta, sp. nov.}

Oblong, robust. Black, opaque; antennæ, palpi, front and middle legs in great part, and some spots on head, dull clay yellow; face and front half of thorax of male wholly of the same hue. Head finely, not closely ocellate-punctate. Thorax finely and irregularly punctate, the middle of disk strongly elevated, tuberculate and with a shallow median sulcus, the sides and posterior declivity of the elevation strigose-punctate. Tegmina oblong, each with a subsutural row of three or four blunt tubercles and several other scattered ones, the intervals between them coarsely, more or less confluently punctate. Pygidium with a narrow, entire median carina between two shorter, broader ones, the intervals coarsely punctate. Hind femora and under surface coarsely punctate. Length male 2.7 ; female $3 \mathrm{~mm}$.

Common throughout Florida on huckleberry and other low shrubs throughout the winter months. This is the species known in most cabinets as Exema conspersa Mann., and has been distributed by me under that name. On taking the true conspersa, which is very scarce in Florida, I sent specimens of both to the U.S. National Museum, and H. S. Barber replied that the larger one above described was in the museum collection under the name conspersa var., some specimens also having been labeled $E$. dispar Lec. On a recent visit to Cambridge, I found that the smaller form was the one there recognized as $E$. conspersa, and as the larger and more common one appears to have no name, I have given it that of neglecta.

Exema conspersa Mannerheim. This is a much smaller $(1.8-2 \mathrm{~mm}$.), more subquadrate species than neglecta and usually has both thorax and elytra distinctly maculate with brownish-yellow. The thorax is without strigæ, its punctures more numerous, much deeper. The elytra are more rugose with crests of tubercles longer, more narrow, and the punctures much smaller. A single specimen is in the National Museum from Enterprise, Fla. About Dunedin I have taken it on several occasions by sweeping weeds about the margins of low, moist, cultivated tracts. It ranges from Florida to California and Mexico.

As pointed out to me by $\mathrm{Mr}$. Barber (Ms.) my Chlamys nodulosa ${ }^{12}$ is probably a synonym of Exema gibber Fabr. It was originally described from 
Charleston, S. Car., and occurs in both bronzed and opaque black forms. The description of Fabricius mentions the black form only.

Metachroma terminale Horn. Frequent at both Cape Sable and Key West on the foliage of shrubs in hammocks. The elytra vary much in colour, being sometimes wholly dull yellow, again uniform pitchy black without the terminal pale spot on which the specific name was based.

\section{Metachroma testacea, sp. nov.}

Form short, robust. Head and thorax reddish-brown, remainder of body a uniform testaceous. Head coarsely, shallowly and irregularly punctate. Thorax semi-elliptical, much wider and with sides less declivent than in $M$. pellucidum; sides and hind angles broadly rounded, disk finely, rather closely, evenly and sharply punctate. Elytra one-third longer than wide; striæ near suture distinctly impressed, those on sides scarcely so, all with distinct rows of round punctures separated by two-thirds their own diameter. Abdomen rather finely and very sparsely punctate. Length $2.3-2.5 \mathrm{~mm}$.

A small species of the form and size of $M$. pellucidum Crotch, but much duller in colour, with different form of thorax and with elytral striæ all entire and punctate throughout their length. It was taken in some numbers by beating and sweeping at Key West, March 1-3. Specimens were submitted to Mr. Fall, who states that he has it unnamed in his collection and considers it an undescribed form.

Trirhabda virgata Lec. One specimen taken at light at Dunedin, July 1, was sent to me by my son. No definite Florida record can be found. Horn states that it "Occurs on the Atlantic coast from Massachusetts to Florida, from which point to Texas it is replaced by brevicollis." It is frequent throughout Indiana.

\section{Galerucella bivittata, sp. nov.}

Elongate-oblong. Dull clay yellow; antennæ and occiput entirely deep black; labrum, mesosterna, sides of abdomen and tarsi piceous black; thorax with a median stripe and a spot each side black; elytra each with a broad submarginal and a narrow subsutural stripe, the two broadly united at tip, deep black. Thorax transversely elliptical, about one-half wider than long, angles all rounded, disk concave each side of the median line, very finely and sparsely punctate, each puncture bearing a very short, fine, appressed hair. Elytra elongate-oval, margins not explanate, disk densely and coarsely punctate, each puncture bearing a silken yellowish semi-prostrate hair; middle coxæ contiguous. Under surface minutely punctate, very finely pubescent. Length $4.5 \mathrm{~mm}$.

Two specimens swept from huckleberry blossoms near Dunedin, March 21. The wholly black antennæ and occiput and bivittate elytra distinguish it from all other described species.

Longitarsus subcylindricus, sp. nov.

Elongate-oval or subcylindrical. Dull reddish-brown; basal half of antennæ, under surface and legs paler reddish-brown; apical half of antennæ fuscous. Head smooth, occiput strongly convex. Second, third and fourth joints of antennæ subequal in length, two-thirds the length of fifth. Thorax subcylindrical, scarcely longer than wide, disk convex, sides strongly declivent, 
their margins feebly curved, surface finely and very shallowly punctate. Elytra conjointly elongate-oval, widest at middle, three times as long as wide, not wider at base than thorax, humeri and umbones wholly absent, disk with fine shallow substriate, close-set punctures. Abdomen smooth. Length $1.8 \mathrm{~mm}$.

Very distinct in its elongate subcylindrical form, being widest at middle of elytra and tapering gradually but very feebly both ways. The surface is not alutaceous but appears subopaque, due to the numerous shallow punctures. It is probably apterous. Known from a single specimen taken by beating in Skinner's Hammock near Dunedin, March 27. Not in either the Leconte or Horn collections, and unknown to Fall.

Coptocycla repudiata Suffr. Twenty or more specimens of this tortoise beetle were taken at Cape Sable from among the bases of the tufts of a coarse grass growing on the open prairie. It was described from Cuba and is recorded by Barber $^{13}$ from Haw Creek, Crescent City and Cocoanut Grove, Fla.

\section{Metriona ormondensis, sp. nov.}

Broadly ovate or subcylindrical. Above dull yellow; elytra with a broad, purplish-red stripe, extending obliquely from humerus to middle of lateral declivity of each strongly convex elytral disk, thence curving outward to margin near apical fourth; thorax and broadly flattened crescentic middle third of each elytral margin translucent yellow; eyes and under surface deep black; legs and joints 1-8 of antennæ pale yellow; joints $9-11$ of antennæ fuscous. Thorax transversely elliptical, nearly twice as wide as long, its front margin very broadly curved, front angles narrowly rounded, surface reticulate and with a few scattered punctures near middle and at base. Elytra strongly elevated at middle with sides of elevation almost perpendicular; margins strongly explanate; disk with rows of round, shallow punctures, separated by about their own diameters, those on basal third and near humeri somewhat confused. Abdominal segments finely and sparsely punctate. Length $6 \mathrm{~mm}$; breadth $5 \mathrm{~mm}$.

Described from two specimens taken from wild morning-glory at Ormond, Fla., April 13, 1913. Much larger than $M$. purpurata (Boh.), with flattened margins of elytra much wider, thorax wider and proportionally shorter and colour very distinctive. It is probably the same as the specimen referred to by Barber (loc. cit., p. 125) as being in the Schæffer collection from Florida. Barber considered that to be only a geographic race of purpurata.

Chelymorpha geniculata Boh. This large Chrysomelid was common and mating along the beach at Long Key, Feb. 27 on the foliage of the creeping goat's-foot morning-glory, Ipomøa pes-capre Sweet. It was taken on the same vine at Cape Sable, Key West and Dunedin, and I believe that to be its true, perhaps only, food plant in Florida. In my opinion this species should be placed as distinct from our northern C. cassidea Fabr. (argus Herbst.). In addition to the very different hue and much smaller black spots it is always narrower and more oblong in form.

Branchus floridanus Lec. A single specimen of this large, oval, gray, scaly Tenebrionid was found lying on its backin a roadway, but alive and kicking, at Key West. It was described ${ }^{14}$ from Florida without definite locality and Schwarz lists it as "On Atlantic seashore, very rare."

13. Proc. Entom. Soc. Wash., XVIII, 1916, 123 ,

14, Smiths. Misc, Coll, No, 167, 1866, 111, 
Polypleurus geminatus Sol. This is also apparently a scarce species. It has not been recorded from Florida. One specimen was taken near Lakeland, Feb. 15, beneath a large pine chip, and another at Dunedin, Dec. 25, by beating Spanish moss. Horn in his Revision of the family says that it occurs in the "Southeastern United States." The closely allied P. perforatus Germ., is listed by Schwarz from Enterprise as "very rare." The third and only other known species, $P$. nitidus Lec., is common beneath bark and logs about Dunedin and elsewhere in southern Florida throughout the winter.

Blapstinus alutaceus Casey. Three specimens of this scarce species were taken, one at Cape Sable, by beating dead branches, the others at Key West by sifting dead leaves. It was previously known only from Key West and Buck Key, Fla., and Texas. First described ${ }^{15}$ by Leconte as B. opacus, which name was preoccupied.

Acanthinus trifasciatus Fabr. A single specimen of this West Indian species was taken from beneath a chunk on the beach at Cape Sable. It is also known from Key West.

Pomphopœa femoralis Lec. Two specimens of this large and brilliant Meloid have been in my collection unnamed since January, 1913, when they were taken at light at Dunedin. I supposed them to be some introduced tropical form which I could not place by the literature available. They were finally named for me by A. J. Mutchler of the American Museum of Natural History. Leconte described ${ }^{16}$ the species from Louisiana, as Lytta femoralis, but it was afterwards erroneously placed as a synonym of $P$. polita Say by Horn. ${ }^{17}$ The head and thorax are a shining bronze, while the elytra are of a brilliant coppery hue.

\section{DIVISION OF FOREIGN INSECT PESTS SUPPRESSION.}

In an endeavcur to prevent the further spread of the apple sucker (Psyllia mali Schmid) by artificial means, a quarantine has been placed on the infested district in the vicinity of Wolfville, N.S. No apple stock, including seedlings, scions, buds or grafts may be removed from the quarantined area unless it is accompanied by a certificate of inspection.

The Brown Tail Moth work in New Brunswick was closed down in the middle of January. No nests have been found during the past two years. Only four men were employed this season, and the greater portion of the territory was scouted with the aid of a car. In Nova Scotia 267 Brown Tail nests were collected up to January $31 \mathrm{st}$; this is a considerable reduction as compared with previous years. The brown tail is still continuing to breed in this Province, and local infestations are uncovered from time to time. The majority of scouts were discharged on January 31 st.

15. Proc. Amer. Phil. Soc., XVII, 1878, 420.

16. Proc. Acad. Nat. Sci. Phil., VI, 1853, 336.

17. Proc. Amer. Phil. Soc., XIII, 1873, 116. 


\section{$2 \mathrm{BHL}$ Biodiversity Heritage Library}

Blatchley, W. S. 1920. "Notes on the winter Coleoptera of western and southern Florida, with descriptions of new species. -II." The Canadian entomologist 52, 68-72. https://doi.org/10.4039/Ent5268-3.

View This Item Online: https://www.biodiversitylibrary.org/item/22190

DOI: https://doi.org/10.4039/Ent5268-3

Permalink: https://www.biodiversitylibrary.org/partpdf/17023

\section{Holding Institution}

MBLWHOI Library

\section{Sponsored by}

MBLWHOI Library

\section{Copyright \& Reuse}

Copyright Status: NOT_IN_COPYRIGHT

This document was created from content at the Biodiversity Heritage Library, the world's largest open access digital library for biodiversity literature and archives. Visit BHL at https://www.biodiversitylibrary.org. 